This work is licensed under Creative Commons Attribution 4.0 International (CC BY 4.0). [http://creativecommons.org/licenses/by/4.0/]

\title{
Kreowanie poczucia kobiecości poprzez filmy animowane Walta Disneya
}

Arleta Witek | Uniwersytet Gdański, Wydział Nauk Społecznych https://orcid.org/0000-0002-6360-8385

\section{Streszczenie}

Słowa kluczowe:

księżniczka,

kobiecość,

popkultura, film animowany, Disney
Keywords: princess, femininity, pop culture animated film, Disney
W artykule prezentuję postacie księżniczek Disneya, czyli bohaterek serii filmów animowanych opartych na klasycznych baśniach. Przybliżam ich historię oraz rolę, jaką odgrywają współcześnie w popkulturze. Poruszam również zagadnienia dotyczące kreowania poczucia kobiecości oraz jej wzorcowych cech. Zwracam uwagę na obecność stereotypów w filmach animowanych, przede wszystkim związanych z kształtowaniem płci.

Media za pomocą filmów animowanych kształtują dziecięce postawy i normy społeczne, które przenikają do życia codziennego i funkcjonują jako trwałe schematy zachowań. Księżniczka Disneya to dla małych odbiorczyń nie tylko animowana postać z filmu, ale również „przyjaciółka”, która jest wzorem do naśladowania, ikoną kulturową dzieciństwa oraz symbolem idealnej dziewczynki, która w przyszłości ma się stać idealną kobietą.

The creation of femininity sense through Walt Disney's animated films Summary

In my article I will try to present characters of Disney princesses, that is, the heroines of a series of animated films based on classic fairy tales. I will present their history and the role they play in contemporary pop culture. I also discuss issues related to creating a sense of femininity and its exemplary features. I focus on the presence of stereotypes in animated films, primarily related to gender formation.

By means of animated films, the media shapes children's attitudes and social norms that penetrate into everyday life and function as permanent models of behavior. Disney Princess is not only an animated character from the film for small recipients, but also a "friend" who is a role model, a cultural icon of childhood and a symbol of an ideal girl who in the future becomes an ideal woman. 


\section{Wstęp}

Filmy animowane z udziałem księżniczek pochodzące z wytwórni Walta Disneya podbijają świat od 1937 r., kiedy to na duży ekran weszła pierwsza pełnometrażowa produkcja, jaką była Królewna Śnieżka i siedmiu krasnoludków. Do 2018 r. powstało ponad czternaście filmów oraz dwa seriale o perypetiach księżniczek

Księżniczki Disneya podbiły nie tylko ekran, ale również znaczną część gospodarki. Wytwórnia filmowa ma aktualnie zawarte umowy franczyzowe na liczne produkty, w skład których wchodzą głównie zabawki, ubrania oraz artykuły użytku codziennego. W 2001 r. przyniosły one zysk ze sprzedaży 300 mln USD, ale już w 2011 r. zysk ten wzrósł do około 4 bilionów. Wpływ na strefę ekonomiczną jest jednym z wielu czynników, który sprawia, że księżniczki Disneya zajmują poważne miejsce nie tylko w świecie filmu, ale również w kulturze popularnej. Wytwórnia Walta Disneya jest wszechobecna w życiu dziewczynek między trzecim a dziesiątym rokiem życia i to one są jej głównymi odbiorcami (England, Descartes, Collier-Meek 2011).

\section{Kim są księżniczki Disneya?}

Pod nazwą "księżniczki Disneya” kryje się 13 postaci pochodzących z 12 różnych filmów animowanych, powstałych między 1937 a 2014 r. Współcześni badacze podzielili te produkcje na trzy okresy: wczesne, pośrednie oraz najbardziej aktualne filmy.

Pierwszym pełnometrażowym filmem animowanym, który został wyprodukowany przez wytwórnię Walta Disneya w 1937 r., była Królewna Śnieżka i siedmiu krasnoludków. W 1950 r. wyszła na ekrany kin kolejna animacja z księżniczką w roli głównej, był to Kopciuszek. Natomiast 9 lat później debiutowała Śpiąca Królewna. Śnieżka, Kopciuszek i Aurora są bohaterkami adaptacji klasycznych baśni, których autorstwo jest przypisywane braciom Grimm (Bettelheim 2010: 392). Jednak od oryginału dzieli je długa droga. Pierwowzory disnejowskich produkcji były pełne okrucieństwa, przemocy i krwi. W niczym nie przypominały opowieści o delikatnych i subtelnych księżniczkach. Klasyki braci Grimm zostały przerobione na baśnie dla dzieci, które z kolei wytwórnia Walta Disneya poddała kolejnej obróbce. W ten sposób z często makabrycznych historii powstały przemiłe opowieści o szczęśliwych zakończeniach.

Śnieżka, Kopciuszek i Aurora zaliczają się do tzw. wczesnej epoki księżniczek. Prezentują cechy tradycyjnie przypisywane kobietom. Są uległe, nie walczą o zdobycie swojego celu, lecz powierzają swój los dziełu przypadku. Ich szczęście zależy od innych osób, na których polegają. Ponadto ich największą ambicją jest znalezienie prawdziwej miłości, od której zależy ich szczęście. Księżniczki są pasywne, w kłopotach pomagają im zwierzęta, które są spersonifikowane i traktowane jako przyjaciele. Bohaterki również zajmują się na co dzień szeregiem prac związanych z gospodarstwem domowym, które tradycyjnie są uważane za kobiece aktywności. Z zadowoleniem wyrażonym poprzez śpiew sprzątają, gotują, piorą (Davis 2014). Królewny z pierwszej epoki 
idealnie wpisują się w model Feminine mystique, wykreowany przez Betty Friedan (1963), która w swojej książce opisywała patriarchalny model społeczny jako służący kobiecie, w którym to może się ona spełniać jedynie poprzez bycie żoną, matką i gospodynią domową. Kobiece aspiracje miały się do tego ograniczać (Rogers 2003: 63). Ewentualne podjęcie pracy zarobkowej zawsze wiązało się z obowiązkiem, nie traktowano go jako szans na rozwój i zaistnienie (Mikulska, Boski 1999: 223).

Relacja miłosna między księciem a księżniczką jest wątkiem przewodnim animacji pierwszej epoki, to ona nadaje opowieściom sens. Dodatkowo wydaje się o tyle ciekawa, że we wszystkich trzech najwcześniejszych filmach mamy do czynienia z miłością od pierwszego wejrzenia. Bohaterki zakochują się w mężczyznach, których zazwyczaj widziały tylko jeden raz wżyciu. Jednakże to jedno spotkanie wywiera na obu stronach tak wielkie wrażenie, że oboje wiedzą, że jest to prawdziwa miłość, która jest w stanie przetrwać wszystko, nawet śmierć. Wątek uczucia silniejszego niż śmierć możemy odnaleźć w aż dwóch filmach: Królewna Śnieżka oraz Śpiq̨ca królewna.

Po dokładnie 30 latach przerwy na duży ekran trafiła adaptacja Hansa Christiana Andersena Mała syrenka, zaczynając etap środkowych filmów. Tytułowa bohaterka Ariel różni się od swoich poprzedniczek, jest bardziej niezależna i samodzielnie dąży do swojego celu. Jednakże jej cel pozostaje taki sam - wielka miłość. Syrenka zakochuje się w człowieku, który nie wie nawet o jej istnieniu. Dla możliwości spotkania się z nim jest gotowa na wiele poświęceń oraz podejmuje ogromne ryzyko dla osiągnięcia swojego celu. Ariel jest postacią, która działa, a nie tylko biernie czeka aż szczęście samo ją odnajdzie.

Po premierze Małej syrenki wytwórnia Disneya nie czekała z kolejnymi filmami tak długo jak wcześniej i już dwa lata później w 1991 r. debiutowała Piękna i Bestia. Film nie jest po raz pierwszy adaptacją klasycznej baśni, a opiera się na ludowej legendzie pochodzenia francuskiego. Tytułowa bohaterka Bella nie przypomina już swoich poprzedniczek. Współcześnie, prawie 30 lat po premierze Pięknej i Bestii, jest uważana za ikonę kobiety wyzwolonej, inteligentnej oraz dążącej do swoich celów, które po raz pierwszy nie są matrymonialne. Dziewczyna nie marzy o szczęśliwej miłości, ale poszukuje wiedzy, chce się uczyć i wyrwać z zaściankowego miasteczka, gdzie nie znajduje zrozumienia wśród pozostałych mieszkańców. Jest gotowa poświęcić się dla dobra ojca, ale nie jest to już bierne poświęcenie i rezygnacja z własnych aspiracji. Charakteryzuje się odwagą, jest w stanie zmierzyć się twarzą w twarz z dziką bestią. Cech, które uznawane są za typowo męskie, a które posiada Bella, nie znajdziemy u bohaterek wczesnych filmów.

Druga odsłona księżniczek Disneya pełna jest nowości. Zaledwie rok po premierze Pięknej i Bestii wchodzi na ekrany Alladyn. Po raz pierwszy w tytule filmu nie pojawia się wskazanie na księżniczkę i nie jest ona tytułową postacią. Alladyn jest jedynym filmem, gdzie mężczyzna a nie księżniczka jest głównym bohaterem. Jasmina, córka sułtana, odgrywa rolę drugoplanową. Kolejna nowość to zmiana miejsca akcji. Dotąd było ono 
nieznane, w Alladynie przenosimy się do świata kultury Wschodu. Pierwszy raz księżniczka jest też spoza obszaru urody i kultury europejsko-amerykańskiej. W 1995 r. ma natomiast premierę Pocahontas, która jest całkowicie odmienna od poprzednich księżniczek, posiada zdecydowanie więcej cech męskich niż kobiecych, a co najistotniejsze - pierwszy raz film nie kończy się ślubem. Bez klasycznego szczęśliwego zakończenia film odbiega konwencją od pozostałych. Ostatnią z bohaterek środkowej ery jest Mulan (1998 r.). Mulan jest bohaterką pochodzenia azjatyckiego i podobnie jak jej poprzedniczka jest bohaterką bardziej męską. W filmie dziewczyna przebiera się za młodego chłopca, by ocalić starszego ojca od walki w wojsku. Dodatkowo od początku filmu możemy zaobserwować, że zachowania typowo kobiece są dla niej uciążliwe.

W środkowym etapie filmów Disneya możemy dostrzec, że bohaterki stają się coraz bardziej niezależne i mniej kobiece niż te w pierwszym etapie. Co ciekawe, wiąże się to ze zmianą ich pochodzenia kulturowego. Pojawia się zależność: im więcej cech typowo męskich u księżniczki, tym bardziej egzotyczne jest jej pochodzenie (Davis 2014).

Ostatni, najbardziej współczesny etap filmów o księżniczkach otwiera Księżniczka i żaba (2009 r.). Animacja zwiastuje rewolucję, ponieważ Tiana jest pierwszą czarnoskórą księżniczką. Zmiana koloru skóry głównej bohaterki wydaje się być związana z ruchem na rzecz walki z rasizmem oraz ukłonem w stronę czarnoskórej publiczności. Jednakże do ciekawostek możemy zaliczyć fakt, że Tiana jest też pierwszą bohaterką, która poza zawodem bycia księżniczką jest jednocześnie właścicielką restauracji. Nie boi się ona wysiłku i czy to nie przypadek, że akurat czarnoskóra księżniczka pracuje zarobkowo? (England, Descartes, Collier-Meek 2011).

Zysk, jaki przyniósł film, okazał się znacznie niższy niż wytwórnia przewidywała. Pojawił się w związku z tym pomysł, by nie tytułować animacji dla najmłodszych w sposób wskazujący, że jest to produkcja wyłącznie dla dziewczynek. Rok później, w 2010 r., wytwórnia wypuszcza mocno różniącą się od oryginału adaptację Roszpunki pt. Zaplątani. Zgodnie z zamierzeniem firmy tytuł nie wskazuje na perypetie królewny. Za to po długiej przerwie ma miejsce powrót do hollywoodzkiego ideału piękna. Roszpunka ma jasną karnację oraz bardzo długie blond włosy. Widać również znaczną zmianę w animacji, w Zaplątanych na polu graficznym nastąpił olbrzymi postęp technologiczny, przez co bohaterka różni się od wcześniejszych księżniczek. Natomiast w kwestii charakteru nie jest ona tak pasywna jak pierwsza trójka, ale przejawia więcej wycofanych zachowań niż jej poprzedniczki z drugiej epoki.

Rok 2013 przyniósł wielki hit ostatnich lat, którego popularność wciąż się utrzymuje z niesłabnącą siłą, jest nim Kraina lodu, luźna adaptacja Królowej Śniegu Andersena. Bohaterkami animacji są dwie siostry, które nie powielają standardowego modelu księżniczki. Młodsza z nich Anna nawiązuje swoją odważną postawą do drugiej ery. Jest waleczna, dzielna, silna, nie potrafi elegancko się zachować. Nie jest już klasyczną ikoną kobiecości. Natomiast jej starsza siostra Elsa, bóstwo współczesnych 
dziewczynek, to całkowicie inny charakter. Elsa ma wiele cech, które po raz pierwszy ukazują się w świecie Disneya. Mimo że opowieści o księżniczkach są przepełnione magią i czarami, to żadna z nich nie dysponuje magiczną mocą. Elsa jest pierwszą bohaterką, która ją posiada. Aczkolwiek jej lodowa siła wydaje się być jej przekleństwem, dziewczyna nie panuje nad nią. Staje się przez to odizolowana zarówno od rodziny, jak i od społeczeństwa. Z tego powodu Elsa jest porównywana do osób niepełnosprawnych lub chorych. Jej moc należy ukrywać, ponieważ to czyni ją inną, dziwną, chorą. Odmienna od reszty musi zostać ukryta, nikt nie może się dowiedzieć o istnieniu mocy (Resene 2017). Jednocześnie Elsa jest pierwszą z księżniczek, która nie ma swojego ukochanego. Doprowadziło to do przywłaszczenia postaci przez ruchy na rzecz równouprawnienia związków homoseksualnych.

\section{Siła stereotypu: kobiecość, gender i seksizm w świecie Disneya}

Kobiecość jest obok męskości jedną z dwóch podstaw społecznej tożsamości płci, która odzwierciedla się w sferze codzienności poprzez świadomość, co to znaczy być i czuć się kobietą (Kopciewicz 2003: 119). Kobiecość wiąże się z atrakcyjnością fizyczną, przez co skupia się na wyglądzie zewnętrznym, czyli prezentacji ciała, fryzurze, makijażu oraz ubraniu (Kopciewicz 2003: 121). Bohaterki Disneya zawsze wyglądają nienagannie, a także dobierają odpowiednio kreację do okazji. Ich stroje akcentują kobiecość. Księżniczka niesie przesłanie dla dziewczynek, że wygląd jest ważną cechą kobiety iże to on wpływa na postrzeganie ich przez mężczyzn (Rogers 2003: 46). Disney we współpracy z firmami kosmetycznymi sprzedaje kosmetyki z wizerunkiem księżniczek dla dziewczynek w wieku 6-9 lat. Dziewczynki już są uczone zamiłowania do kosmetyków i dbałości o własny wygląd (Rogers 2003: 171). Przyczyny tego można doszukiwać się w zjawisku, jakim jest nowe dziewczęctwo (ang. new girlhood), definiowane jako przynależność do płci kulturowej oraz odzwierciedlane poprzez konsumpcyjny styl życia, który promują produkty Disneya. Zatem współczesne społeczeństwo wywiera od najmłodszych lat presję na dziewczynkach, aby wypełniały oczekiwania narzucane im przez kulturę masową i podążały za ideałem obecnym w mediach (Kopciewicz, Zierkiewicz 2009: 123).

Teoria ról społecznych powstała, ponieważ kobiety i mężczyźni historycznie zajmowali się zupełnie innymi dziedzinami życia, a także przypadały im odmienne obowiązki. Różnica między płciami wynika więc z różnic kulturowych a nie biologicznych. Kobiety i mężczyźni zachowują się podobnie w społeczeństwach, w których mają równorzędny status (Mikulska, Boski 1999: 53). To kultura kształtuje psychologię płci poprzez socjalizację płciową (Mikulska, Boski 1999: 57). Za pośrednictwem otoczenia, w którym istotną rolę odgrywają także media, dzieci uczą się zachowań przypisywanych dla danej płci. Kultura masowa mocno wyodrębnia role płciowe (Kopciewicz, Zierkiewicz 2009: 124). 
W ojczyźnie Walta Disneya, czyli Stanach Zjednoczonych, studia nad popkulturą oraz filmem animowanym są bardzo szeroko rozwinięte. Pierwsze badania nad rolą płci w amerykańskiej telewizji podjęli Thompson i Zerbinos w 1995 r. Przeanalizowali 175 odcinków pochodzących z 41 kreskówek o różnej tematyce. Wśród głównych wątków wyłoniły się na motywy: przygodowe, edukacyjne, rodzinne oraz komediowe. W produkcjach poddanych analizie pojawiło się wiele stereotypów płciowych, a także seksizm oraz rasizm wyrażający się poprzez wąską talię i duży biust bohaterek czy bardzo jasny kolor cery postaci o wyższej pozycji społecznej. Największą częstotliwość występowania stereotypowych wzorców zarejestrowano w produkcjach przygodowych, zaś najmniejszą w edukacyjnych. Rok 1980 można uznać za swoistą granicę w zmianie modelu wzorców postępowania kreowanych przez telewizję. Od tego momentu zmniejsza się ilość cech tradycyjnie kobiecych pośród żeńskich bohaterek. Media za pomocą filmów animowanych kształtują dziecięce postawy i normy społeczne, które przenikają do życia codziennego i funkcjonują jako trwałe schematy zachowań. Postrzeganie płci jest jednym z aspektów, na które media mają największy wpływ. Kreują one zrozumienie wierzeń i znaczeń przypisanych płci oraz pokazują, które działania są postrzegane jako normalne. Przykładem mogą być romantyczne zachowania, takie jak randkowanie, które ukazuje społecznie przyjęty skrypt i przyczynia się do zrozumienia normy obowiązującej w danej kulturze (England, Descartes, Collier-Meek 2011).

Stereotyp płciowy zawiera w sobie specyficzne atrybuty oraz zróżnicowane wzorce zachowań, które tradycyjnie są przypisywane chłopcom lub dziewczynkom. Są one ukryte nawet w zabawkach, które zaznaczają i umacniają różnice płciowe od samego dzieciństwa. Od razu widać, które zabawki są skierowane dla kogo oraz determinują one schematy postępowania chłopców i dziewczynek (Rogers 2003: 163). Popularność księżniczek Disneya, z którymi idą w parze stereotypy płciowe, nasuwa refleksję na temat współczesnych koncepcji kobiecości. Z badań wynika, że w XXI w. dziewczynki wciąż akceptują i internalizują tradycyjny model kobiecości. Wizerunek disnejowskiej bohaterki pokazuje postać z przewagą cech statycznych, która zdaje się na działania otoczenia, sama nie podejmuje własnych aktywności, na rzecz osiągnięcia swojego celu. Dodatkowo księżniczka charakteryzuje się niewinnością, ofiarnością, uprzejmością oraz opiekuńczością. Zaś w sferze fizycznej charakteryzuje się delikatnymi dłońmi, szczupłą sylwetką oraz dużym biustem. W ten sposób wykreowany zostaje wąski ideał kobiecego piękna, z którym identyfikują się dziewczynki. Dążenie do nieracjonalnych standardów, na które są wystawione dziewczynki, wywołuje w nich niepokój i może zwiększać podatność na depresję w dorosłym życiu.

Dotychczas powstało wiele tekstów dotyczących bezpośrednio księżniczek oraz rozważań nad ich miejscem w kulturze. Aktualnie najpopularniejszym motywem, jaki możemy zaobserwować w amerykańskich badaniach, jest głośny w ostatnich latach problem gender. Zauważalna ewolucja zachowań księżniczek na przestrzeni 
dziesięcioleci wiąże się z kwestią płci kulturowej. Duża grupa rozważań zauważa narastającą niezależność głównych bohaterek.

W amerykańskich badaniach, którym swój artykuł poświęciły Dawn E. England, Lara Descartes i Melissa A. Collier-Meek, wyłoniły się trzy hipotezy:

- odbiorcy oczekują, że księżniczki pokażą więcej cech charakteru, które tradycyjnie przypisuje się kobietom, zaś książęta więcej cech męskich;

- księżniczka powinna być ratowana, natomiast książę powinien ją ratować;

- widzowie spodziewają się bardziej zrównoważonych cech płciowych bohaterów wraz z coraz późniejszymi filmami.

Cechy męskie (cechy przypisywane książętom) to:

- ciekawość księżniczki - wiąże się z zainteresowaniem, jakie książęta wykazują wobec żeńskich postaci, uważają oni kobiety za zniewalające, urzekające czy też mistyczne (ta cecha nigdy nie występuje u księżniczek);

- chęć odkrywania - wyraża się poprzez poszukiwanie nowych przygód, rozpatrywanie, dowiadywanie się tego, co nieznane;

- siła fizyczna;

- asertywność - książę pozostaje uprzejmy, ale w jego słowach dostrzegalna jest nutka grozy;

- nieemocjonalność - książę hamuje wszelkie uczucia i emocje, zarówno pozytywne, jak i negatywne;

- niezależność;

- atletyczność - wyraża się poprzez np. zamiłowanie do sportów;

- zaangażowanie w aktywność intelektualną - książę lubi czytać, posiada i zdobywa wiedzę o otaczającym go świecie;

- wzbudzanie strachu - postać księcia budzi respekt;

- odwaga;

- dawanie porad;

- przywództwo, bycie liderem.

Cechy kobiece (cechy przypisywane księżniczkom) to:

- słabość fizyczna;

- uległość;

- pokazywanie emocji - księżniczka nie hamuje uczuć, np. gdy jest smutna, zaczyna płakać;

- czułość, bycie kochającym wobec innych;

- pielęgnacja, wychowanie - są pokazane poprzez opiekuńczość wobec innych, często zwierząt;

- wrażliwość;

- niepewność;

- pomocność;

- kłopotliwość - związana jest z powodowaniem problemów, na które inni muszą szukać rozwiązań; 
- bojaźliwość - szczególnie przed śmiercią i złem;

- zawstydzenie;

- załamujący się płacz - został wyodrębniony jako oddzielna cecha, polega na ukrywaniu twarzy w dłonie, łóżko itd. podczas płaczu, przez co widz nie jest w stanie zobaczyć łez księżniczki;

- opisywane jako piękne - inni bohaterowie w ten sposób postrzegają księżniczki;

- prośby o radę i pomoc - kobiety potrzebują asysty fizycznej i emocjonalnej w działaniach, które podejmują;

- bycie ofiarą - księżniczki są tymi postaciami, którym grozi poddawanie torturom, ponoszą one dotkliwe straty fizyczne lub utratę własności poprzez okrucieństwo i opresyjne traktowanie; czynnikiem, elementem, który definiuje ten kod, jest fizyczna krzywda, szkoda, nadużycie (England, Descartes, Collier-Meek 2011).

Cechy książąt i księżniczek były kodowane oddzielnie, ze względu na posiadanie lub zachowanie, nowe zachowanie kodowane było za każdym razem, gdy zmienia się scena. Wnioskiem z powyższych badań jest ewolucja zachowań księżniczek od cech typowo kobiecych do cech tradycyjnie przypisywanych mężczyznom. Delikatne i pasywne bohaterki w nowszych filmach stają się coraz bardziej niezależne (England, Descartes, Collier-Meek 2011).

\section{„Być jak księżniczka” - wzorce zachowań i ideały postępowania współczesnych dziewczynek}

Księżniczka Disneya to dla dziewczynek nie tylko animowana postać z filmu, ale „przyjaciółka", która jest wzorem do naśladowania, ikona kulturowa dzieciństwa i symbol idealnej dziewczynki, która w przyszłości ma się stać idealną kobietą. Dlatego pojawia się wątek utożsamienia z księżniczkami. Dziewczynki są fankami i wielbicielkami księżniczek, chciałyby być takie jak one.

Na podstawie badań empirycznych z udziałem dziewczynek w wieku od 3 do 9 lat, takich jak obserwacja lub wywiad, wyłoniły się cztery wątki podejmowane podczas zabaw w księżniczki. Trzy pierwsze, związane z dbałością o wygląd, strój oraz mowę ciała, odnoszą się do motywu kobiecego. Zaś ostatni z nich wiąże się z wykluczeniem chłopców ze świata księżniczek. Co doprowadza do wyraźnego podziału płciowego już wśród najmłodszych dzieci (Golden, Jacoby 2017).

Motyw powtarzający się prawie we wszystkich produkcjach: główna bohaterka to kobieta, będąca zazwyczaj księżniczką, oraz książę, który jest związany z nią miłosnym uczuciem. Szczęśliwe zakończenie zależy od znalezienia prawdziwej miłości. Dajemy dziewczynkom jednowymiarowy wzór kobiecości i poczucia szczęścia.

Wizerunek kobiety, który jest przekazywany dziewczynkom poprzez media, jest statyczny oraz ograniczony. Stereotyp kobiecy wywiera negatywny wpływ na dziewczynki i młode kobiety, szczególnie na ich zdrowie psychiczne. Standardy piękna pokazywane w mediach powodują konsekwencje w myśleniu dziewczynek oraz 
kształtowanie konkretnych postaw wobec jedzenia. Dzieje się tak, ponieważ jest prezentowany wąski ideał kobiecego piękna, za którym młode odbiorczynie zaczynają podążać (Golden, Jacoby 2017).

\section{Zakończenie}

Ze współczesnych badań nad filmem animowanym, które szczególnie szeroko są podejmowane w Stanach Zjednoczonych, wynika, że wymyślone bohaterki mają ogromny wpływ na kształtowanie postaw oraz sposobów myślenia najmłodszych. W filmach oraz filmowych gadżetach są poukrywane znaczenia związane z płcią kulturową, rasizmem, a także wiele stereotypów, które wciąż oddziałują na dzieci. Dobrym przykładem tego zjawiska są księżniczki Disneya. Piękne, młode i szczupłe dziewczyny, które swoim zachowaniem pokazują dziewczynkom, jaka powinna być idealna kobieta.

\section{Bibliografia}

Bettelheim B., 2010, Cudowne i pożyteczne. O znaczeniach i wartościach baśni, Warszawa.

Davis M., 2014, From Snow to Ice: A Study of the Progression of Disney Princesses from 1937 to 2014. Film matters, http://www.micheleleigh.net/wp-content/uploads/2014/01/snow-to-ice.pdf [dostęp: 13.01.2018].

England D.E., Descartes L., Collier-Meek M.A., 2011, Gender Role Portrayal and the Disney Princesses. Sex Roles, http://fliphtml5.com/wmuo/ohda/basic [dostęp: 20.11.2017].

Golden J.C., Jacoby J.W., 2017, Playing Princess: Preschool Girls' Interpretations of Gender Stereotypes in Disney Princess Media. Sex Roles, https://link.springer.com/article/10.1007/s11199-017-0773-8 [dostęp: 14.01.2018].

Kopciewicz L., 2003, Polityka kobiecości jako pedagogika różnic, Kraków.

Kopciewicz L., Zierkiewicz E. (red.), 2009, Dziwki, królowe i szare myszki, czyli gimnazjalna codzienność widziana przez pryzmat seksualizacji dziewczyństwa: Koniec mitu niewinności? Płeć i seksualność w socjalizacji i edukacji, Warszawa.

Mikulska J., Boski P. (red.), 1999, Męskość i kobiecość w perspektywie indywidualnej i kulturowej: Przyczyny różnic płciowych. Dylematy i rozstrzygnięcia, Warszawa.

Resene M., 2017, From Evil Queen to Disabled Teen: Frozen Introduces Disney's First Disabled Princess, "Disability Studies Quarterly", http://dsq-sds.org/article/view/5310/4648 [dostęp: 7.01.2018].

Rogers M., 2003, Barbie jako ikona kultury, Warszawa.

\section{Biogram}

Arleta Witek - absolwentka historii sztuki oraz pedagogiki na Uniwersytecie Gdańskim, doktorantka w Instytucie Pedagogiki Wydziału Nauk Społecznych UG. Zainteresowania badawcze: kobiecość w kulturze, edukacja alternatywna, ochrona praw zwierząt. 